\title{
Monostotic fibrous dysplasia: a case report with cone-beam computed tomography findings
}

\author{
Displasia fibrosa monostótica: relato de caso por meio de achados de tomografia computadorizada de \\ feixe cônico
}

Eliana Dantas da COSTA ${ }^{1}$

Priscila Dias PEYNEAU'

Francielle Silvestre VERNER ${ }^{2}$

Solange Maria de ALMEIDA'

Glaucia Maria Bovi AMBROSANO'1

\begin{abstract}
Fibrous dysplasia is a benign fibrous-osseous lesion in which normal bone is replaced by fibrous connective tissue and immature bone, affecting only one (monostotic) or several bones (polyostotic) and mainly occurring in children and young adults. When present in facial bones, the maxilla is more frequently involved than the mandible, which can cause facial asymmetry in addition to dental complications. In the image exams, the main characteristic of fibrous dysplasia is its unpolished glass appearance. Computed tomography is the ideal method for evaluating this lesion and its relationship with adjacent structures. The use of conventional radiography, due to the overlapping of anatomical structures, makes it difficult to delineate the extension of the lesion. The present study is aimed at guiding dentist-surgeons on the main imaging characteristics of fibrous dysplasia by describing a case of a female 10-year-old patient presenting with this lesion in the maxilla.
\end{abstract}

Indexing terms: Cone-beam computed tomography. Fibrous dysplasia monostotic. Maxilla.

\section{RESUMO}

A displasia fibrosa é uma lesão fibro-óssea benigna em que o osso normal é substituído por tecido conjuntivo fibroso e osso imaturo, podendo afetar um único osso (monostótica) ou vários ossos (poliostótica), ocorrendo principalmente em crianças e adultos jovens. Quando presente nos ossos faciais, a maxila é envolvida com mais frequência que a mandíbula, podendo causar assimetria facial, além de complicações odontológicas. Nos exames por imagem a característica principal da displasia fibrosa é a aparência de vidro despolido. A tomografia computadorizada é o método ideal para avaliação dessa lesão e relação com estruturas adjacentes. A radiografia convencional, devido a sobreposição de estruturas anatômicas, torna difícil a delimitação da extensão da lesão. O presente estudo teve como objetivo apresentar o relato de caso de um paciente do sexo feminino, 10 anos de idade, com presença de displasia fibrosa na maxila, objetivando orientar os cirurgiões-dentistas com relação às principais características imaginológicas dessa lesão.

Termos de indexação: Tomografia computadorizada de feixe cônico. Displasia fibrosa monostótica. Maxila.

\section{INTRODUCTION}

Fibrous dysplasia (FD) is a rare benign fibroosseous lesion ${ }^{1-7}$ characterised by the gradual replacement of the normal bone by fibrous tissue and immature bone $e^{5,8}$. Although its aetiology is unknown, it is thought that FD may be of genetic or traumatic origin.

Clinically, FD can be classified as monostotic when limited to only one bone and polyostotic when more bones are involved ${ }^{1-2,5-13}$. The monostotic FD is the most common form, representing 70 to $85 \%$ of the cases ${ }^{7,13}$ and mainly occurring in the bones of the face, with the maxilla being more frequently affected than the mandible $1-2,8,10,14-16$. In this type of FD, man and women are affected with the same frequency ${ }^{7,12-13,17}$.
The polyostotic form is rarer and mainly occurring in long bones ${ }^{6,10}$ and possibly associated with McCune-Albright syndrome, which is characterised by the presence of coffee-milk cutaneous pigmentation and endocrinopathy $1,3,6-10,16,18$. This type is more frequent in women and may cause precocious puberty $1,3,10-11,13-14,18-19$. Other syndrome less common than polyostotic FD may be associated with Mazabraud syndrome, which is characterised by the involvement of soft tissues with presence of intra-muscular myxomas ${ }^{5,11-12,16,20}$.

When FD reaches the sphenoid, temporal, zygomatic and frontal-nasal bones of the maxilla and skull base is termed as craniofacial FD',8,11-12,20. The most common clinical symptom in the cases of craniofacial FD is a painless swelling in the region involved, including facial

\footnotetext{
1 Universidade Estadual de Campinas Faculdade de Odontologia de Piracicaba, Departamento de Diagnóstico Oral - Área de Radiologia Odontológica. Av. Limeira, 901, Areião, 13414-903, Piracicaba, SP, Brasil. Correspondência para / Correspondence to: ED COSTA. E-mail: <elianusp@yahoo.com.br>.

2 Universidade Federal de Juiz de Fora, Departmento de Odontologia. Juiz de Fora, MG, Brasil.
} 
asymmetry which may cause severe deformity resulting in functional and aesthetic compromise ${ }^{6,20}$. Craniofacial FD may also be associated with dental problems, such as malocclusion $4,9,16,20-21$, changes in tooth positioning and prolonged retention of deciduous teeth (9), thus affecting mastication and speech ${ }^{21}$.

Conservative treatment is usually based on treating asymptomatic cases of $\mathrm{FD}^{6}$. Indications for surgical treatment include the following: aesthetic correction, functional deformity, prevention of pathological fracture or removal of symptomatic lesions. It is important to pay attention to the moment of surgery, since monostotic lesions tend to be inactivated after skeletal maturation, whereas the polyostotic ones remain active during the adult phase ${ }^{13}$.

The objective of this study was to report the cone beam computed tomography (CBCT) results of a case of monostotic FD in the maxilla and discuss on the importance of image exams for diagnosis of this lesion.

\section{CASE REPORT}

Female patient aged 10 years old was referred to the radiology department for $\mathrm{CBCT}$ examination to investigate a painless hard oedema on the left side of the maxilla with unknown evolution and absence of painful symptoms. CBCT image revealed a slight facial asymmetry, whereas intra-oral examination showed an increased bone volume in the buccal region, normal sound fibrous mucosa, prolonged retention of tooth \#63 and presence of orthodontic wire for traction of partially-impacted tooth \#21. The patient did not remember to have suffered any trauma on the region.

CBCT examination was performed by using I-Cat CB500 scanner (Imaging Sciences, Hatfield, PA, USA) according to the acquisition protocol as follows: 120 $\mathrm{kVp}, 5 \mathrm{~mA}$, voxel of $0.25 \mathrm{~mm}$ and field of view (FOV) of 13x8. Multiplanar reconstructions (MPR) and 3D volume images were obtained. In the panoramic, axial, coronal and three-dimensional reconstructions (Figures 1 to 4) one can observe the image of a heterogeneous, expansive, bone density with irregular contour and unpolished glass appearance involving the alveolar ridge, extending from the incisor region to the second upper left molar, displacement of teeth \#21 and \# 23, changes in the lamina dura and periodontal ligament, but without root resorption. Discrete invasion of the maxillary sinus was also observed, with the lateral wall being slightly expanded. No involvement of soft tissues was observed either. The diagnostic hypothesis was monostotic fibrous dysplasia. The patient was instructed to undergo imaging examinations regularly so that the lesion's progression could be followed up until skeletal maturity is reached.

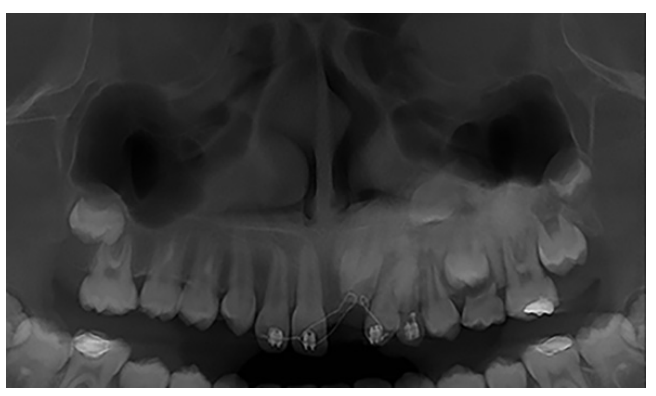

Figure 1. Panoramic reconstruction of the maxilla with $25 \mathrm{~mm}$ in thickness: note the displacement of teeth \#21 and \#23 as well as the absence of lamina dura and narrowing of the periodontal ligament. One can also note discrete invasion of the left maxillary sinus by the lesion, with the lateral wall being slightly expanded.

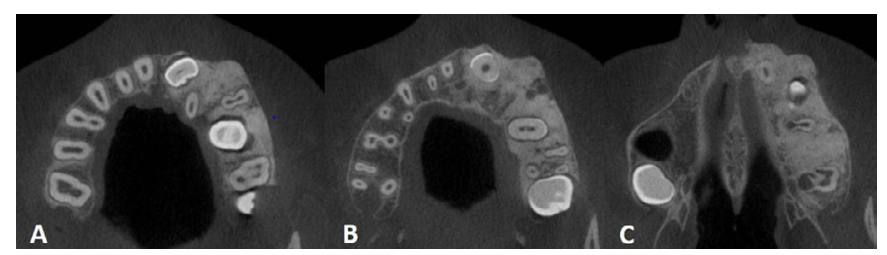

Figure 2. Axial reconstruction of the maxilla: note the well-delimited, heterogeneous, hyperdense image with irregular contour. One can also observe an decreased maxillary sinus volume on the left side in the buccal-lingual sense, that is, located at the anterior region and extending towards the posterior region.

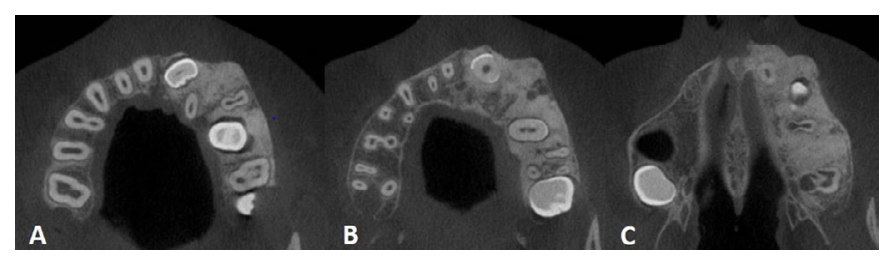

Figure 3. Coronal reconstruction of the maxilla: note the enhanced increase in the anterior region (left side) of the maxilla extending towards the posterior region and then to the left second molar.

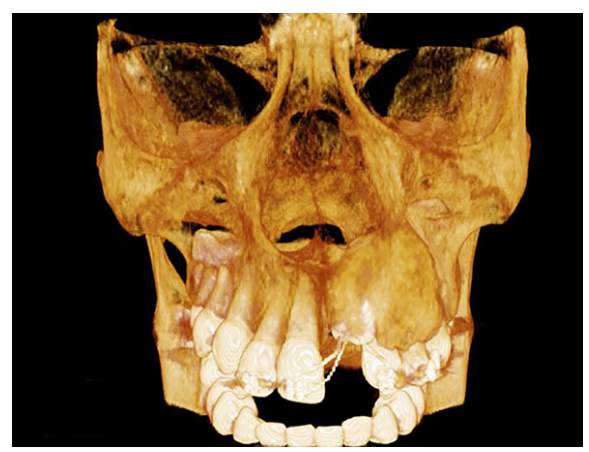

Figure 4. Three-dimensional reconstruction of the mid-third of the face. One can observe slight prominence in the anterior and posterior regions of the left maxilla and partially-included tooth \#21 with presence of orthodontic wire for traction. 


\section{DISCUSSION}

Fibrous dysplasia (FD) is a non-neoplastic benign disorder in which normal bone is replaced by fibrous tissue and immature bone 1,8,12-16,20-21, which may affect one (monostotic) or more bones (polyostotic) ${ }^{14,17,20}$. FD is frequently found in children and young adults ${ }^{6,17}$, such as in the present case of a female 10-year-old patient. In general, the lesion begins in the childhood and progresses during puberty, ceasing after adolescence ${ }^{4}$.

Maxilla and mandible are the most affected bones in the craniofacial region ${ }^{11}$, with the lesion affecting more commonly the posterior than the anterior regions of the $\operatorname{arch}^{2}$ and being more frequent in the buccal region ${ }^{19}$. When present in these regions, FD can cause dental complications such as displacement of maxillary sinus floor and mandibular canal ${ }^{2}$, displacement or retention of teeth, loss of lamina dura, narrowing of the periodontal ligament space, and rarely, root resorption 2,10,17,19. One can also observe that the mucosa covering the affected bone appears to be healthy and normal ${ }^{10,19}$. Dental changes were found as well in the present study, with maxillary volume increasing more in the anterior region of the left hemi-maxilla and extending buccally and lingually.

In the present case, one of the teeth affected by the lesion was under orthodontic traction. According to Akintoye et al. ${ }^{9}$, it is a challenge to perform orthodontic treatments in patients with FD and therefore special care should be paid to the close relationship between lesion and teeth.

FD is a rare but potentially severe disease which can cause fracture when affecting long bones, including osseous pain, deformities and compression of surrounding tissues, ${ }^{1,7}$. Moreover, neurological symptoms such as headache, poor visual acuity, diplopia, paresthesial-2,8,16-17,20-21, nasal obstruction ${ }^{2,16,21}$, hearing loss $^{2,17,20}$ and sinusitis-like symptoms ${ }^{2}$ can occur when craniofacial bones are affected.

In some cases in which FD causes neither painful symptoms $^{7}$ nor aesthetical problems, there is no need of surgical treatment $t^{1,7,10}$, which is recommended when maxilla and mandible are both affected by the lesion ${ }^{1,12}$. Nevertheless, in those cases of mild deformity (as in the present case), it is recommended to follow up the lesion by performing imaging examinations on a periodical basis until skeletal maturity, since relapse is very common following surgical treatment ${ }^{1,12}$.

It is worth emphasising that although FD becomes stable after bone maturation ${ }^{13,15,17-19}$, there are cases in which the lesion can be re-activated or activated during pregnancy, thus suggesting a possible influence of sexual

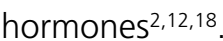

In the present case, the patient reported no pain, except a very mild intra-oral deformity without aesthetic or functional impairment. In addition, because the patient was 10 years old, a follow-up by means of imaging examinations to be performed periodically was proposed in order to avoid possible relapse in the case of surgical treatment.

Other treatment options for FD include the use of bi-phosphates ${ }^{1,7,11-13}$ to assist in the decrease of bone resorption and of the risk of fracture and malignant transformation ${ }^{3-4,8,12-14,16-17,19}$.

As the majority of the monostotic lesions are asymptomatic, they are only discovered by means of imaging examinations ordered for other purposes ${ }^{13,20}$. Due to the unpolished glass appearance of FD on the images ${ }^{13}$, the imaging diagnosis is enough and thus bone biopsy is not necessary ${ }^{8,13}$

In addition, according to Assaf et al. ${ }^{16}$, the diagnosis of FD is based on imaging examinations such as panoramic radiography, $\mathrm{CT}$ and $\mathrm{CBCT}$, with histopathological evaluation being performed when surgical treatment is indicated.

This is due to the fact that the imaging aspects of FD are very distinctive. Therefore, the presence of bone expansion, thin cortex, well-defined borders and unpolished glass appearance $e^{2-3,6,9,11,16-19}$ is observed on these images. The unpolished glass appearance is due to the mixed mineralisation pattern of the lesion, that is, radiolucent areas corresponding to predominant fibrous tissue and more radiopaque areas corresponding to the bone tissue content ${ }^{19-20}$. It is worth emphasising that the initial lesions are more radiolucent, becoming more radiopaque as the lesion develops ${ }^{1,6,12}$.

CT has been used for precise evaluation of localisation and extension of $\mathrm{FD}^{6,20}$ and follow-up of patients ${ }^{17}$ since 1970 . Therefore, the introduction of CBCT in dentistry also promoted its use for diagnosing FD ${ }^{16-17}$ not only because of the advantages of less radiation dosage and less cost compared to $C T$, but also because of its better image quality for hard tissues ${ }^{22-25}$.

According to Hanifi et al. ${ }^{11}$, CT examination enables us to visualise precisely the extension of the lesion and its relationship with surrounding tissues as well as its inner structure in detail. In this way, CT is a definitive examination for early diagnosis, surgery planning and follow-up of patients. On the other hand, the conventional radiography 
does not allow the lesion's extension and delimitation to be observed due to the overlapping of anatomical structures.

The imaging findings showed three possible patterns of FD depending on the amount of fibrous and osseous tissue, namely: unpolished glass aspect, homogeneous density and cystic variety with predominance of fibrous tissue ${ }^{8,20}$. However, in the majority of the cases, the unpolished glass appearance was the most prevalent image $e^{8,16}$

CT examination also provides information on the lesion's extension, presence of cortical erosions not visible on conventional radiographs and occurrence of fissures ${ }^{6}$. In the present case, the CBCT images showed a dense expansive mass limited to the maxilla, with appearance of unpolished glass.

Although some studies reported the indication of magnetic resonance imaging (MRI) for diagnosis of $\mathrm{FD}^{6,20,26}$, this type of examination does not reveal the distinctive characteristic of FD as observed in radiographs and CT images ${ }^{6,8,20}$, since the lesion may often be confounded with tumours ${ }^{6,8}$. Therefore, MRI can be used for evaluation of more complex cases of FD such as patients with compression of neurological structures, involvement of soft tissues and pre-surgery evaluation of vascular structures ${ }^{6}$.

On the other hand, CT is the imaging modality of choice for diagnosis of FD in patients with suspicious lesions, typical symptoms (e.g. oedema and facial asymmetry) $)^{6,19}$ and follow-up due to its high accuracy and specificity ${ }^{6,14}$.

According to Lisle et al. ${ }^{20}, \mathrm{CT}$ should be used as a first-line investigation in patients with the typical symptoms of FD, such as swelling and facial asymmetry, as well as for confirmation of suspicious lesions on conventional radiographs. Moreover, CT can be used to complement the diagnosis and improve the interpretation of MRI examinations of lesions in the bones of skull base and face, since the appearance of unpolished glass will confirm the diagnosis of FD.

The differential diagnosis of FD includes osteomyelitis, osteosarcoma ${ }^{17}$ and cemento-ossifying fibroma ${ }^{1,3,17-18}$. Among these lesions, one can observe

\section{REFERENCES}

1. Alvares LC, Capelozza ALA, Cardoso CL, Lima MC, Fleury RN, Damante JH. Monostotic fibrous dysplasia: a 23-year follow-up of a patient with spontaneous bone remodeling. Oral Surg Oral Med Oral Pathol Oral Radiol Endod. 2009; 107(2):229-34. doi: 10.1016/j.tripleo.2008.10.009 periosteal widening and bone sequestration in the osteomyelitis; characteristic periosteal reaction with sunbeams appearance, cortical destruction and widening of the periodontal ligament space ${ }^{2}$ in the osteosarcoma ${ }^{17}$; and ossifying fibroma with precise limits, smooth margins and concentric expansion ${ }^{1,17-18}$.

According to Lisle et al. ${ }^{20}$, the differential diagnosis of FD is very simple as in the majority of the lesions one should consider the patient's age, symptom progression and presence of the unpolished glass appearance on the imaging examinations.

Therefore, we have reported a typical case of monostotic FD with involvement of the maxilla and the importance of $C T$ and $C B C T$ examinations for precisely evaluating the lesion's limits and injury of surrounding structures and for diagnosis of this rare lesion.

\section{CONCLUSION}

The increased familiarity with the imaging characteristics of fibrous dysplasia can assist the dentistsurgeon in the early diagnosis and treatment of patients. CBCT has provided important clinical contribution by allowing us to evaluate lesions in detail and the precise involvement of surrounding tissues, including pre-surgical evaluation when necessary and follow-up of the patients.

\section{Collaborators}

ED COSTA was responsible for bibliographic update, discussion and article writing, review and critical analysis of the content of the article. PD PEYNEAU was responsible for images evaluation, review and critical analysis of the content of the article. FS VERNER was responsible for images evaluation, review and critical analysis of the content of the article. SM ALMEIDA contributed to the review and critical analysis of the content of the article. GMB AMBROSANO contributed to the review and critical analysis of the content of the article.

2. Neves FS, Bastos LC, Santos LAN, Crusoé-Rebello I, Campos PSF. Displasia fibrosa: abordagem tomográfica. Rev ABRO. 2010;11(1):23-26.

3. Kruse A, Pieles U, Riener MO, Zunker Ch, Bredell MG, Grätz KW. Craniomaxillofacial fibrous dysplasia: A 10-year database 1996-2006. Br J OralMaxillofac Surg. 2009; 47(4):302-5. doi: 10.1016/j.bjoms.2009.01.008 
4. Park BY, Cheon YW, Kim YO, Pae NS, Lee WJ. Prognosis for craniofacial fibrous dysplasia after incomplete resection: age and serum alkaline phosphatase. Int J Oral Maxillofac Surg. 2010 Mar;39(3):221-6. doi: 10.1016/j.ijom.2009.12.008

5. Li L, Hou X, Qiwei Li Q, Zhang L. En bloc resection and bone graft: does it alter the natural history of monostotic expansile fibrous dysplasia in children? World J Surg Oncol. 2014;12:349. doi: 10.1186/1477-7819-12-349

6. Atalar MH, Salk I, Savas R, Uysal IO, Egilmez H. CT and MR imaging in a large series of patients with craniofacial fibrous dysplasia. Pol J Radiol. 2015; 80: 232-40. doi: 10.12659/ PJR.893425

7. Kutbay NO, Yurekli BS, Baykan EK, Sahin SB, Saygili F. Characteristics and treatment results of 5 patients with fibrous dysplasia and review of the literature. Case Rep Endocrinol. 2015;2015:1-7.

8. Celenk P, Zengin Z, Muglali M, Celenk C. Computed tomography of cranio-facial fibrous dysplasia. Eur J Radiol. 2009;69(3):e85-e87. doi: 10.1016/j.ejrex.2008.09.004

9. Akintoye SO, Lee JS, Feimster T, Booher S, Brahim J, Kingman $A$, et al. Dental characteristics of fibrous dysplasia and McCune-Albright syndrome. Oral Surg Oral Med Oral Pathol Oral Radiol Endod. 2003;96(3):275-82. doi: 10.1016/S10792104(03)00225-7

10. Pagotto LEC, Mariani PB. Displasia fibrosa monostótica da maxila: revisão da literatura e relato de 2 casos. Rev Cir Traumatol BucoMaxilo-fac. 2009;9(2):23-32.

11. Hanifi B, Samil KS, Yasar C, Cengiz C, Ercan A, Ramazan D. Craniofacial fibrous dysplasia. Clin Imaging. 2013 NovDec;37(6):1109-15. doi: 10.1016/j.clinimag.2013.01.010

12. Jeyaraj $C P$, Srinivas $C V$. Craniofacial and monostotic variants of fibrous dysplasia affecting themaxillofacial. J Oral Maxillofac Surg. 2014;26(3):424-31. doi: 10.1016/j.ajoms.2013.05.011

13. Adetayo OA, Salcedo SE, Borad V, Richards SS, Workman AD, Ray AO. Fibrous dysplasia: an overview of disease process, indications for surgical management, and a case report. Eplasty. 2015; 15:35-46.

14. Abdelkarim A, Green R, Startzell J, Preece J. Craniofacial polyostotic fibrous dysplasia: a case report and review of the literature. Oral Surg Oral Med Oral Pathol Oral Radiol Endod. 2008;106(1):e49-55. doi: 10.1016/j.tripleo.2008.03.023

15. Keskin M, Karabekmez FE, Ozkan BT, Tosun Z, Avunduk MC, Savaci N. Simultaneous occurrence of facial fibrous dysplasia and ameloblastoma. J Craniomaxillofac Surg. 2009 Mar;37(2):1025. doi: 10.1016/j.jcms.2008.10.015
16. Assaf A, Benecke AW, Riecke B, Zustin J, Fuhrmann AW, Heiland $M$, et al. Craniofacial fibrous dysplasia (CFD) of the maxilla in an 11-year old boy: a case report. J Craniomaxillofac Surg. 2012;40(8):788-92. doi: 10.1016/j.jcms.2012.02.016

17. Erzurumlu ZU, Celenk P, Bulut E, Baris YS. CT imaging of craniofacial fibrous dysplasia. Case Rep Dent. 2015;2015: 134.

18. Yasuoka T, Takagi N, Hatakeyama D, Yokoyama K. Fibrous dysplasia in the maxilla: possible mechanism of bone remodeling by calcitonin treatment. Oral Oncol. 2003;39(3):301-5. doi: 10.1016/S1368-8375(02)00037-4

19. Junqueira JLC, Silva MBF, Lopes MRM, Júnior LRCM, Oliveira LB, Araújo NS. Displasia fibrosa: a doença e a imagem. Rev Assoc Paul Cir Dent. 2010;64(2):128-33.

20. Lisle DA, Mounsour PA, Maskiell CD. Imaging of craniofacial fibrous dysplasia. J Med Imaging Radiat Oncol. 2008;52(4):32532. doi: 10.1111/j.1440-1673.2008.01963.x

21. Chen $M$, Yang C, Fang B, Zhang S, Xu K. Treatment of Hemimandibular Fibrous Dysplasia With Radical Excision and Immediate Reconstruction With Free Double Costochondral Graft. J Oral Maxillofac Surg. 2010;68(8):2000-2004. J Oral Maxillofac Surg. 2010 Aug;68(8):2000-4. doi: 10.1016/j. joms.2009.09.035

22. Monsour PA, Dudhia R. Implant radiography and radiology. Aust Dent J. 2008 Jun;53(Suppl 1):S11-25. doi: 10.1111/j.18347819.2008.00037.x

23. Tomasi C, Bressan E, Corazza B, Mazzoleni S, Stellini E, Lith A. Reliability and reproducibility of linear mandible measurements with the use of a cone-beam computed tomography and two object inclinations. Dentomaxillofac Radiol. 2011;40(4):244-50. doi: $10.1259 / \mathrm{dmfr} / 1742330$

24. Nogueira AS, Centurion BS, Fernandes AP, Mendes AC, Cardoso LB, Capelozza ALA. Tomografia computadorizada de feixe cônico em implantodontia oral: relato de série de casos. Rev Assoc Paul Cir Dent. 2012;66(3):227-32

25. Sheikhi M, Ghorbanizadeh S, Abdinian M, Goroohi H, Badrian $\mathrm{H}$. Accuracy of linear measurements of Galileos cone beam computed tomography in normal and different head positions. Int J Dent. 2012;2012:214954. doi: 10.1155/2012/214954

26. Parekh SG, Donthineni-Rao R, Ricchetti E, Lackman RD. Fibrous dysplasia. J Am Acad Orthop Surg. 2004;12(5):305-13.

Received on: 17/5/2016

Final version resubmitted on: 19/1/2017

Approved on: 11/2/2017 